\title{
新しく規格化された インターベンショナル基準点についての考察
}

\author{
坂本 肇・相川良人 ${ }^{1 ｝ \cdot \text { 池川博昭 }{ }^{1)} \cdot \text { 佐野芳知 }{ }^{1)} \cdot \text { 荒木 力 }$
}

2004年 2 月16日論文受理

Code Nos. 150

820

山梨大学大学院医学工学総合教育部・医学部附属病院放射線部

1 ) 山梨大学医学部附属病院放射線部

緒

interventional radiology (IVR)の技術進歩に伴い低い 侵襲で高い治療効果が得られることより，血管撮影領 域において診断から治療へと移行する件数は増加傾向 にある，特に，心血管領域においては，デバイスや手 技の進歩が著しくPCI (percutaneous coronary interventional) は多くの施設で行われている.PCIで は, 細いガイドワイヤやバルーン等を目的とする病変 まで誘導しなければならないため, 高解像力・高濃度 分解能を有する透視撮影や長時間に及ぶ透視が必要と
される場合がある。このため，患者の被曝線量が増加 し放射線皮膚障害を起こした事例が，他の分野に比べ 多く報告されている1 4) 。このような，放射線による 確定的影響の発生を防ぐためには，手技中の患者被曝 線量をモニタリングすることが重要である.

心血管撮影領域において患者皮膚線量を測定する場 合, thermoluminescence dosimeter(TLD), skin dose monitor (SDM), 蛍光ガラス線量計などの検出器を直 接皮膚面に貼り付けて測定する直接測定法とnon dosimeter dosimetry (NDD) 表面線量簡易換算法5, 6) や面

\section{Consideration of the Newly Standardized Interventional Reference Point}

\section{HAJIME SAKAMOTO, YOSHIHITO AIKAWA, 1) HIROAKI IKEGAWA, 1) YOSHITOMO SANO, 1) and TSUTOMU ARAKI}

Interdisciplinary Graduate School of Medicine and Engineering, Department of Radiology.

University of Yamanashi

1) Department of Radiology, University of Yamanashi Hospital

Received Oct. 30, 2003; Revision accepted Feb. 16, 2004; Code Nos. 150, 620, 810

\section{Summary}

The interventional reference point is standardized by the International Electrotechnical Commission(IEC), and is adapted to adult cardiovascular studies. We examined the precision of the indicated incident dose at the interventional reference point. As a fundamental examination, we compared entrance phantom dose and incident dose at the interventional reference point. We also compared the entrance skin dose of patients with incident dose at the interventional reference point and evaluated the possibility of clinical application. Results showed that the incident dose at the interventional reference point indicated an underestimation of 0.77 times to an overestimation of 2.2 times when representing entrance surface dose. In clinical application, the incident dose at the interventional reference point calculated from the dose area product tended to overestimate by about 1.17 times the entrance skin dose measured by thermoluminescence dosimeter(TLD). Furthermore, the evaluation varied according to the angles of the $\mathrm{C}$-arm of the $\mathrm{x}$-ray system. A interventional reference point is a useful standard for simple, real-time dose measurement by the indirect method. It is important to understand the characteristics of the indicated incident dose at the interventional reference point in clinical use.

Key words: Interventional reference point, Dose area product, Patient dose control, Entrance skin dose,

Coronary angiography 
積線量計7，8)などから皮膚線量を推定する間接測定法 がある．直接測定法の場合，精度は高いが測定手技が 煩雑でありTLDや蛍光ガラス線量計はリアルタイム性 に久ける．間接測定法では，多方向からの透視撮影の ため焦点皮膚間距離，皮虐入射面積などの幾何学的配 置が変化するため推定を難しくしている。このように 心血管撮影領域での皮膚線量測定法の選択は難しい現 状にあるが，簡便で実用的な測定方法を確立すること は重要である99.

最近，規格化されたインターベンショナル基準点10) は指定された点での線量表示を規定している．基準点 が設定されたことにより，間接測定法での推定が容易 に行えるようになった。 そこで今回われわれは，イン ターベンショナル基準点での表示線量值の精度につい て基礎的，臨床的に検討したので報告する．

\section{1. インターベンショナル基準点}

インターベンショナル基準点 (interventional reference point) は2000年に作成されたinternational electrotechnical commission (IEC) 60601-2-43での医用 電気機器パート2-23：インターベンショナルプロセジ ヤー用X線装置の安全に関する個別要求事項において 規格化された ${ }^{10)}$ ．インターベンショナル基準点は成人 の心臓領域の検查に適用され，その位置はアイソセン タを持つシステムにおいてアイソセンタからX線管焦 点方向に $15 \mathrm{~cm}$ 離れた点である (Fig. 1)。一般的なCア 一ムでのX線管焦点からアイソセンタまで70cmのシス テムにおいて，インターベンショナル基準点は基準軸 に沿ってX線管焦点から $55 \mathrm{~cm}$ の位置となる。また，ア イソセンタを持たないシステムにおいては，製造業者 によって定義された基準軸上の点としている。

本規格による線量表示はインターベンショナル基準 点での空気カーマを基準空気カーマとしている，そし て，X線照射中(装置が負荷状態)では基準空気カーマ 率を表示し，負荷状態でない間は透視と撮影の空気力 一マの合計である積算基準空気カーマを表示するよう な装置のシステムを要求している。ここでの空気カー マ值は測定または計算された值である。なお，本規格 は日本において現在 japanese industrial standards(JIS) 化素案として検討中である.

\section{2. 方法および結果}

\section{2-1 使用機器}

X線装置：BICOR T.O.P.(シーメンス旭メディテッ ク株式会社製)

面積線量計：DIAMENTOR K2(PTW社製) 電離箱線量計：UNIDOS M10001 (PTW社製) プローブ：Model $30006(0.6 \mathrm{cc})$ (PTW社製)

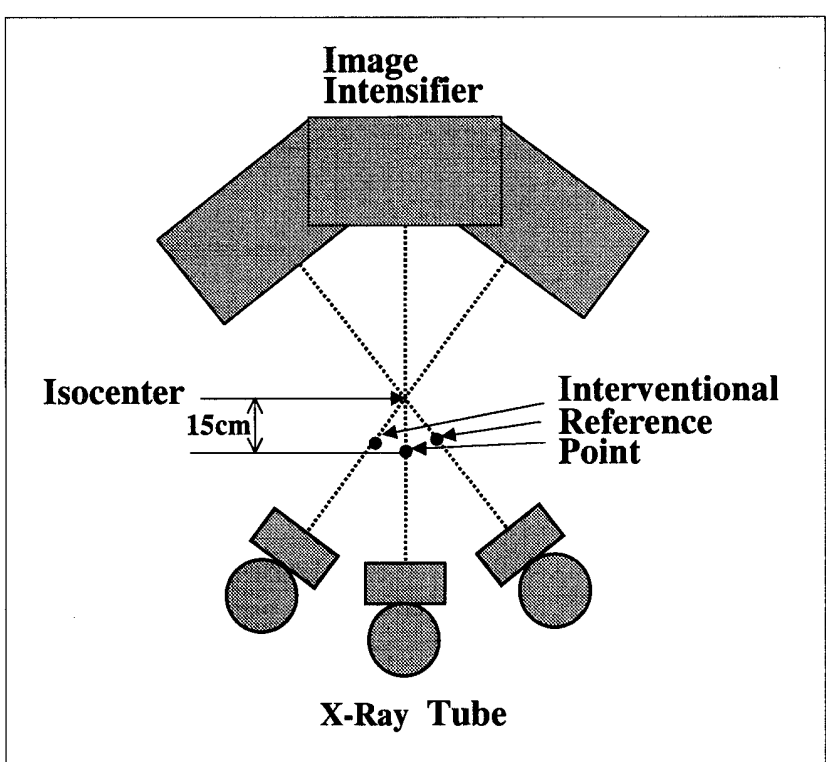

Fig. 1 Geometric position of an interventional reference point.

TLD：UD-170A（松下電器株式会社製）

TLDリーダー：UD-512(松下電器株式会社製)

被写体：アクリル板

面積線量計はX線装置のコリメー夕に内蔵され，面 積線量計とTLDは臨床に扔いて使用頻度が高い管電圧 $70 \mathrm{kV}(35.7 \mathrm{keV})$ にて，リファレンス線量計とした電離 箱線量計で空中にて校正した。

\section{2-2 インターベンショナル基準点での入射線量と入 射表面線量との基礎的検討}

インターベンショナル基準点の一点の入射線量で基 準軸上の他の点の入射表面線量を代表した場合の測定 誤差を検証するため, Fig. 2の幾何学的配置で基礎的 な検討を行った。測定での被写体厚はアクリル板 $20 \mathrm{~cm}$ 用い, image intensifier(I.I.)のサイズは臨床で の心血管造影時に使用する $17 \mathrm{~cm}$ であり，各入射面積 相対值を測定した。また，線量測定点は被写体下にプ ローブを配置し後方散乱を含んだ值を測定し，各線量 相対值を評価した。ささらに，各測定位置での面積線量 も測定した。

\section{2-2-1 焦点-被写体間距離の変化}

焦点-I.I.間距離を $100 \mathrm{~cm}$ 一定とし，焦点-被写体間距 離を50〜79cm と変化させ測定した[Fig. 2(a)].

Fig. 3(a)にインターベンショナル基準点での入射面 積に対する各表面入射面積の相対值(表面入射面積/イ ンターベンショナル基準点での入射面積)を示す．焦 点-被写体間距離が長くなるに従い相対值は大きくな り，I.I.に被写体が接触する $79 \mathrm{~cm}$ では2.1倍の面積比と なった.

Fig. 3(b)にはインターベンショナル基準点での入射 


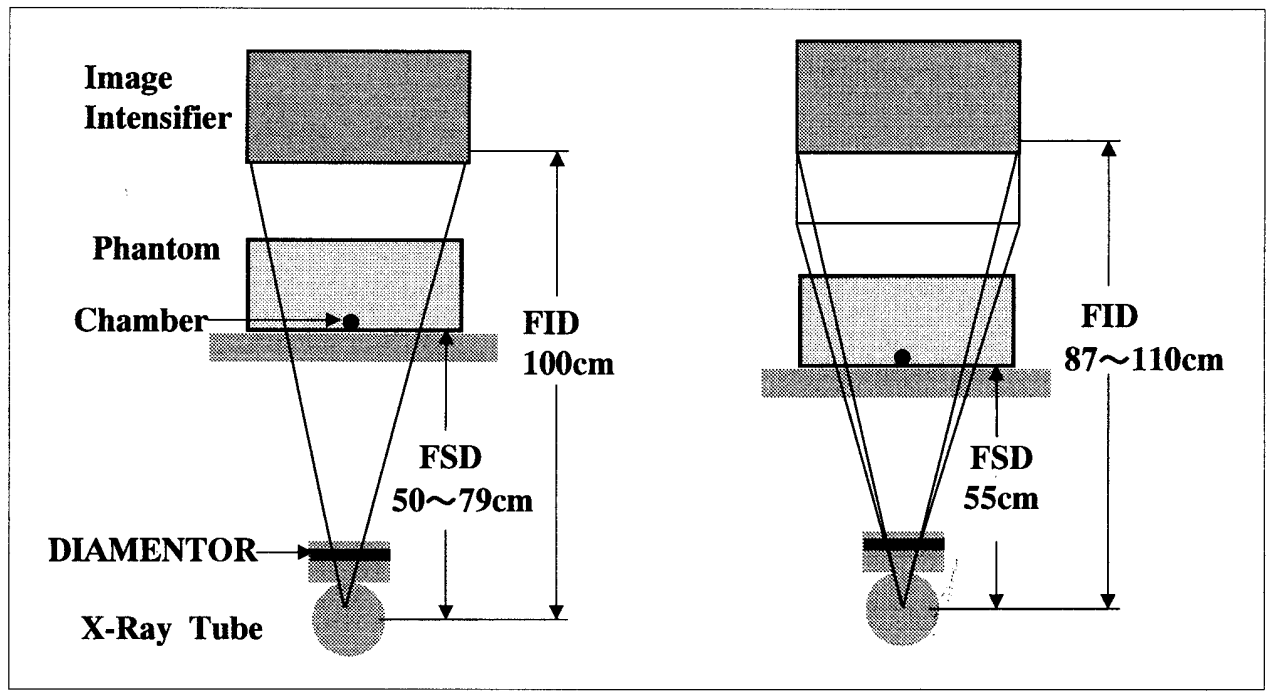

Fig. 2 Geometric arrangement of the fundamental experiment.

(a) Focus-to-subject distance (FSD) changes from 50 to $79 \mathrm{~cm}$ with stable focus to image intensifier (I.I.) distance (FID).

(b) FID changes from 87 to $110 \mathrm{~cm}$ with stable FSD at $55 \mathrm{~cm}$ of focus image intensifier (I.I.) distance (FID).
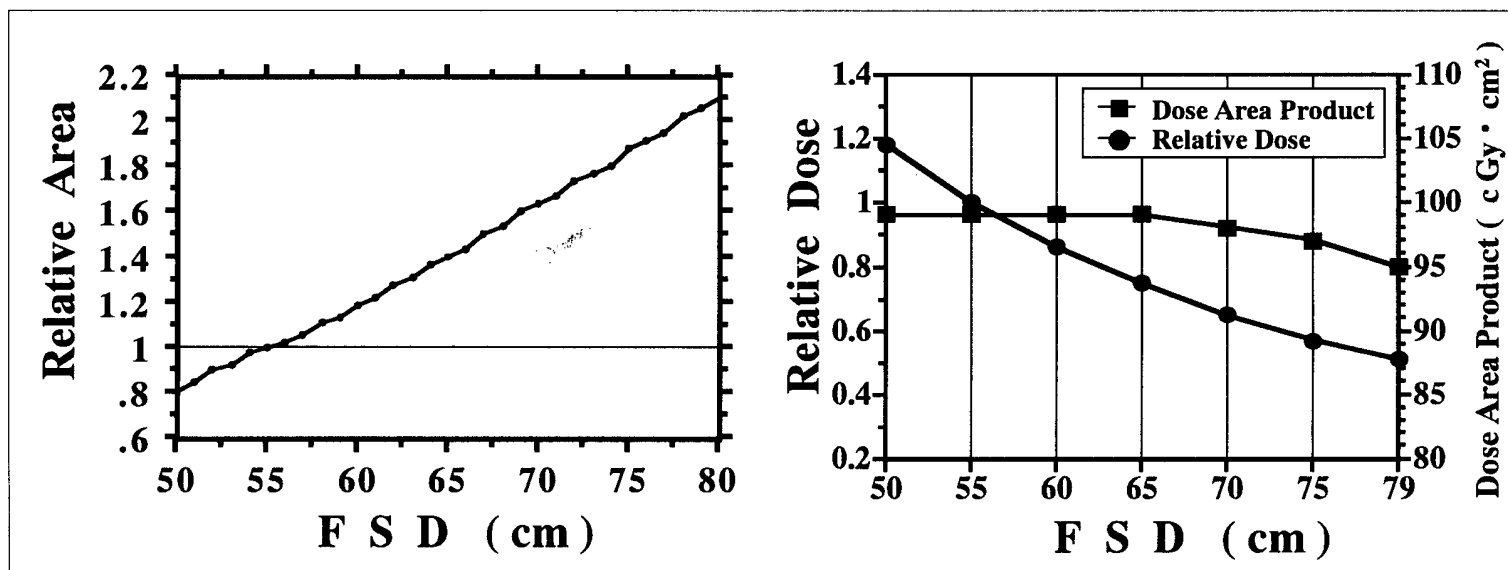

Fig. 3 Relative values of the entrance area and entrance dose for the phantom surface to the interventional reference point according to the FSD value.

(a) Relative area (phantom entrance area / interventional reference point area).

$a \mid b$

(b) Relative dose (entrance phantom surface dose / incident dose at interventional reference point) by ionization chamber value and dose area product value.

線量に対する各入射表面線量の相対值 (入射表面線量) インターベンショナル基準点での表面線量) と面積線 量を示す．焦点-被写体間距離が長くなるに従い相対 值は小さくなり，1.2〜0.5の範囲となった。また，面 積線量は焦点-被写体間距離が長くなるに従い小さく なったが，その変化は少ない結果となった。

\section{2-2-2 焦点-I.I.間距離の変化}

焦点-被写体間距離を $55 \mathrm{~cm}$ (インターベンショナル 基準点)一定とし，焦点-I.I. 間距離を $87 \sim 110 \mathrm{~cm}$ と変化 させ測定した[Fig. 2(b)].

Fig. 4 (a)に焦点-I.I.間距離を $100 \mathrm{~cm}$ での入射面積に
対する各表面入射面積の相対值(表面入射面積/焦点I.I.間距離 $100 \mathrm{~cm}$ での入射面積)を示す. 焦点-I.I.間距離 が長くなるに従い相対值は小さくなり，1.3〜0.8の範 囲となった。

Fig. 4(b) に焦点-I.I.間距離を $100 \mathrm{~cm}$ での入射線量に 対する各入射表面線量の相対值 (入射表面線量/焦点I.I. 間距離 $100 \mathrm{~cm}$ での入射表面線量)を示す．焦点-I.I.間 距離が長くなるに従い相対值は大きくなり，0.9〜1.1 の範囲となった。また，面積線量は焦点-I.I.間距離が 長くなるに従い小さくなり，その变化率は大きい結果 となった。 

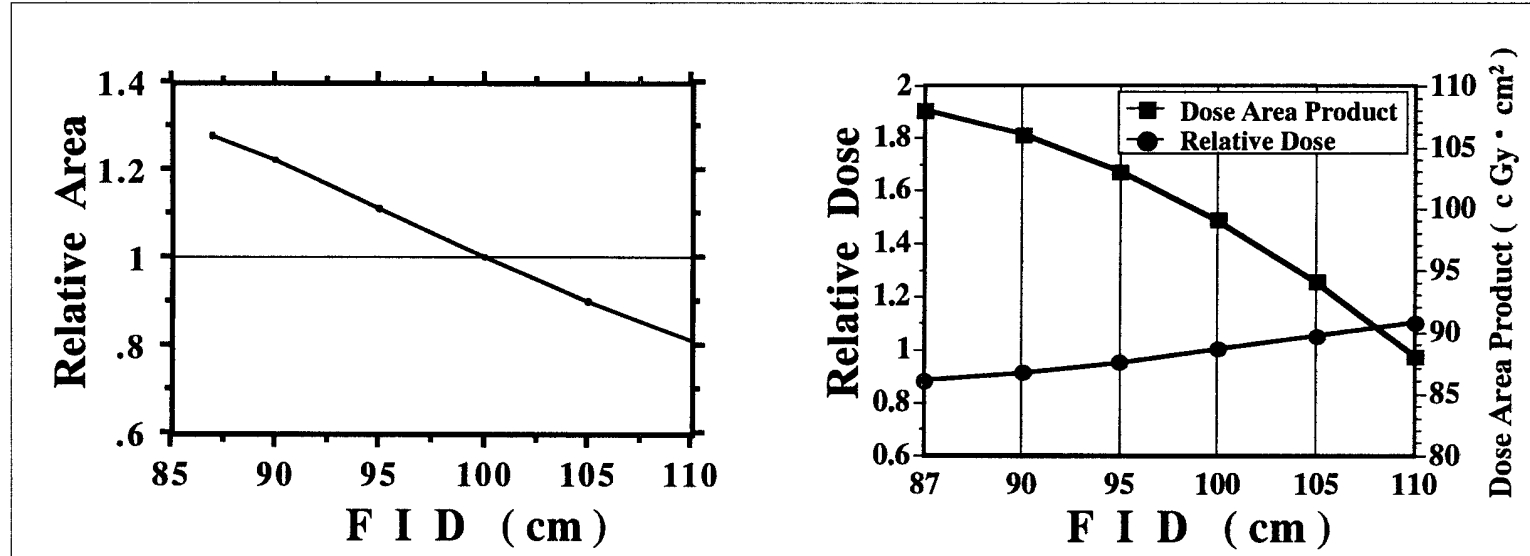

Fig. 4 Relative values of the entrance area and entrance dose for the phantom surface to the interventional reference point according to the FID value.

(a) Relative area (phantom entrance area / phantom entrance area at FID $100 \mathrm{~cm}$ ).

(b) Relative dose (entrance phantom surface dose / entrance phantom surface dose at FID $100 \mathrm{~cm}$ ) by ionization chamber value and dose area product value.
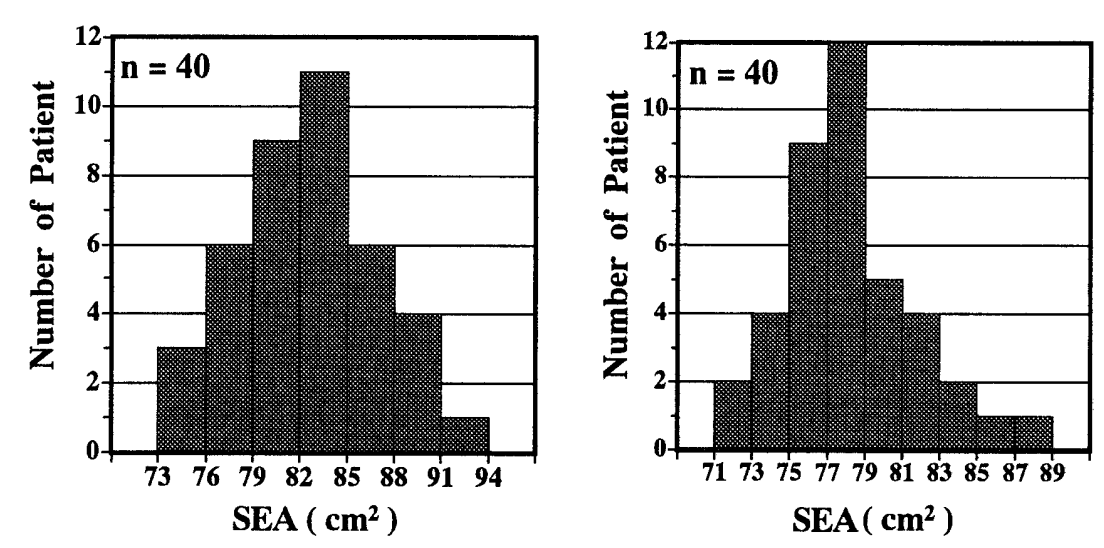

$\operatorname{SEA}\left(\mathrm{cm}^{2}\right)$

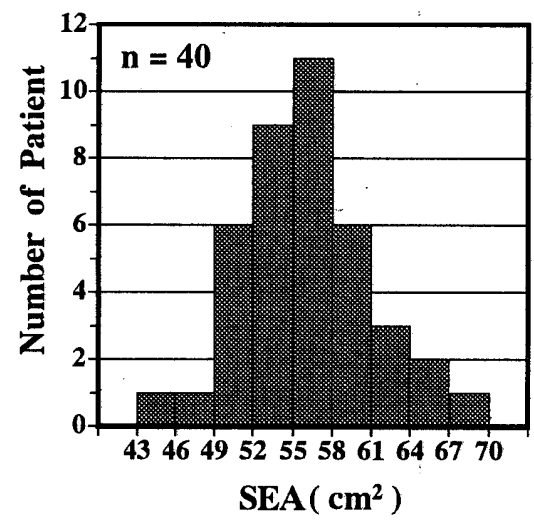

Fig. 5 Relationship between skin entrance area and number of patients.

(a) Postero-anterior direction.

(b) Right anterior oblique direction of 30 degrees.

$a|b| c$

(c) Left anterior oblique direction of 60 degrees.

\section{2-3 臨床応用}

\section{2-3-1 インターベンショナル基準点での入射面積と 皮膚入射面積との関係}

成人心血管検査において，インターベンショナル基 準点での入射面積と実際の皮膚入射面積を比較するた め, 検査中の患者および装置の幾何学的配置を記録 し，検査終了後その配置を再現することにより皮膚入 射面積を実測定した．測定は当施設で最も使用頻度が 高いI.I.サイズ $17 \mathrm{~cm}$, 角度は正面, RAO30度, LAO60

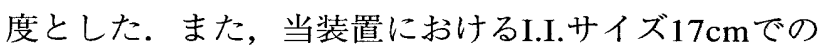
インターベンショナル基準点での入射面積は $56.3 \mathrm{~cm}^{2}$ である。

Fig. 5に皮膚入射面積 (SEA) と患者数の頻度分布を 示す.Fig. 5(a)，(b)より正面，RAO30度での皮膚入
射面積はインターベンショナル基準点での入射面積よ り広い所に分布し，Fig. 5(c)よりLAO60度ではイン夕 一ベンショナル基準点での入射面積をほぼ中心とした 分布となった。 なお, 症例は2-3-2での症例の一部で ある。

2-3-2 インターベンショナル基準点における入射線 量と入射皮膚線量との関係

成人心血管検査において，患者背面に一検査当たり 6〜8 個のTLDを貼り入射皮膚線量を実測定した。同 時に, 面積線量計を用いインターベンショナル基準点 における入射線量を推定し実測値と比較した．測定は 正面, RAO30度, LAO60度の透視撮影角度で行っ た。また，推定は(1)式を用い8), 皮膚入射面積SEAは I.I.サイズ $17 \mathrm{~cm}$ でのインターベンショナル基準点での 

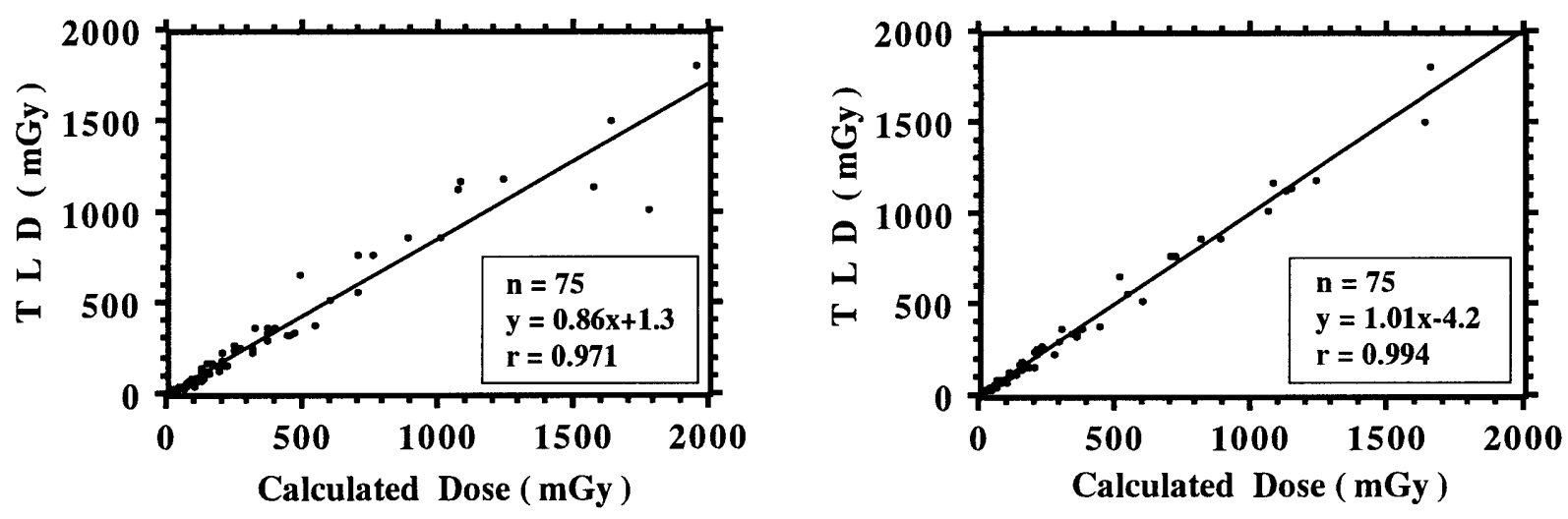

Fig. 6 Entrance skin dose measured by TLD and calculated dose from dose area product meter in clinical setting. (a) Incident dose at the interventional reference point calculated from dose area product.

(b) Entrance skin dose calculated from dose area product.

入射面積 $56.3 \mathrm{~cm}^{2}$, I.I.サイズでの補正係数 I は $17 \mathrm{cmI} . \mathrm{I}$. サイズの1.05をそれぞれ代入し計算した．（1)式を以 下に示す.

$\mathrm{ESD}=(\mathrm{DAP} / \mathrm{SEA}) \cdot \mathrm{I} \cdot \mathrm{T} \cdot \mathrm{F}$

ESD : 入射皮膚線量 $(\mathrm{mGy})$

DAP : 面積線量計の表示值 $\left(\mathrm{mGy} \cdot \mathrm{cm}^{2}\right)$

SEA : 皮膚入射面積 $\left(\mathrm{cm}^{2}\right)$

I : 各I.I.サイズでの補正係数

$\mathrm{T}:$ 検查テーブルの補正係数

$\mathrm{F}$ : 付加フィル夕補正係数

な押，推定值はインターベンショナル基準点上に被 写体があることを想定し，基準点での後方散乱を含ん だ入射皮膚線量 $(\mathrm{mGy})$ である。

Fig. 6(a)にTLDによる実測值と面積線量計から推定 した基準点での入射皮膚線量の関係を示す．TLDの線 量範囲は16.5 1812 m Gyであり, 両者は $\mathrm{y}=0.86 \mathrm{x}+1.3, \mathrm{r}=0.971$ と相関が強く, $\mathrm{p}<0.0001$, $\mathrm{r}^{2}=0.943$ が得られた。 なお，回帰式のyはTLDによる実 測值，xは面積線量から推定した計算値である。ま た，Fig. 6(b)にTLDによる実測值と実測した皮膚入射 面積を用い推定した入射皮虐線量の関係を示す，両者 は $\mathrm{y}=1.01 \mathrm{x}-4.2, \mathrm{r}=0.994$ と相関が強く, $\mathrm{p}<0.0001$, $r^{2}=0.989$ が得られた。

Fig. 7はFig. 6(a)の結果を基に方向別に分類した実 测值とインターベンショナル基準点での入射皮虐線量 の関係を示す。Fig.7(a) は正面の結果であり $\mathrm{y}=0.74 \mathrm{x}+0.18, \mathrm{r}=0.984, \mathrm{r}^{2}=0.967, \mathrm{p}<0.0001$ となり, Fig. 7 (b) はRAO30度の結果であり $\mathrm{y}=0.68 \mathrm{x}+11.0$, $\mathrm{r}=0.984, \mathrm{r}^{2}=0.968, \mathrm{p}<0.0001$ となり, Fig. $7(\mathrm{c})$ は LAO60度の結果であり $\mathrm{y}=0.96 \mathrm{x}+13.0, \mathrm{r}=0.992$, $\mathrm{r}^{2}=0.984, \mathrm{p}<0.0001$ が得られた。

\section{3. 考 察}

心血管撮影領域での患者被曝線量測定は, 多方向透 視撮影や幾何学的配置の变化に伴い患者皮膚面の測定 位置が決定しにくいことなどが困難な原因となってい る. 臨床に扔いて, 簡便であり手技中リアルタイムに 入射皮膚線量をモニタリングすることは，放射線によ る確定的影響の発生を防ぐために最も重要である。こ のため, IECで規格化されたインターベンショナル基 準点は間接測定法を有効利用するための画期的な方法 であると考える。しかし，基準軸上の一点であらゆる 角度・幾何学的配置を推定するため, ある程度の䛊差 を含むと考えられる，そこで本研究は，インターベン ショナル基準点での入射線量值の精度について基礎的 検討を行い, 臨床応用の可能性についても検討した.

\section{3-1 インターベンショナル基準点での入射線量と入 射表面線量との基礎的検討}

インターベンショナル基準点の一点で基準軸上の他 の点の入射表面線量を表示した場合, 焦点-I.I. 問距離 を一定としたFig. 3(b)より, 焦点側に被写体が近づく $50 \mathrm{~cm}$ では実際の線量の 0.85 倍 (相対值の逆数) と過小 評価し，I.I.側に近づく $79 \mathrm{~cm}$ では 2 倍(相対值の逆数) と過大評価をする。これは, 面積線量がほぼ一定(装 置から出力されるX線量がほほ一定)であることに対 し, Fig. 3(a)の入射面積比(距離の逆二乗比)が変化し ているためであると考えられる. また, 面積線量の若 干の低下はグレーデル効果による影響と考えられる.

焦点-被写体問距離を $55 \mathrm{~cm}$ のインターベンショナル 基準点一定としたFig. 4 (b)では, 焦点-I.I. 間距離 $100 \mathrm{~cm}$ での基準点の線量を表示した場合, I.I.が被写体 に近づく $87 \mathrm{~cm}$ では1.1倍 (相対值の逆数) と過大評価 し, 遠ざかる $110 \mathrm{~cm} て ゙ は ~ 0.9$ 倍 (相対值の逆数) と過小 

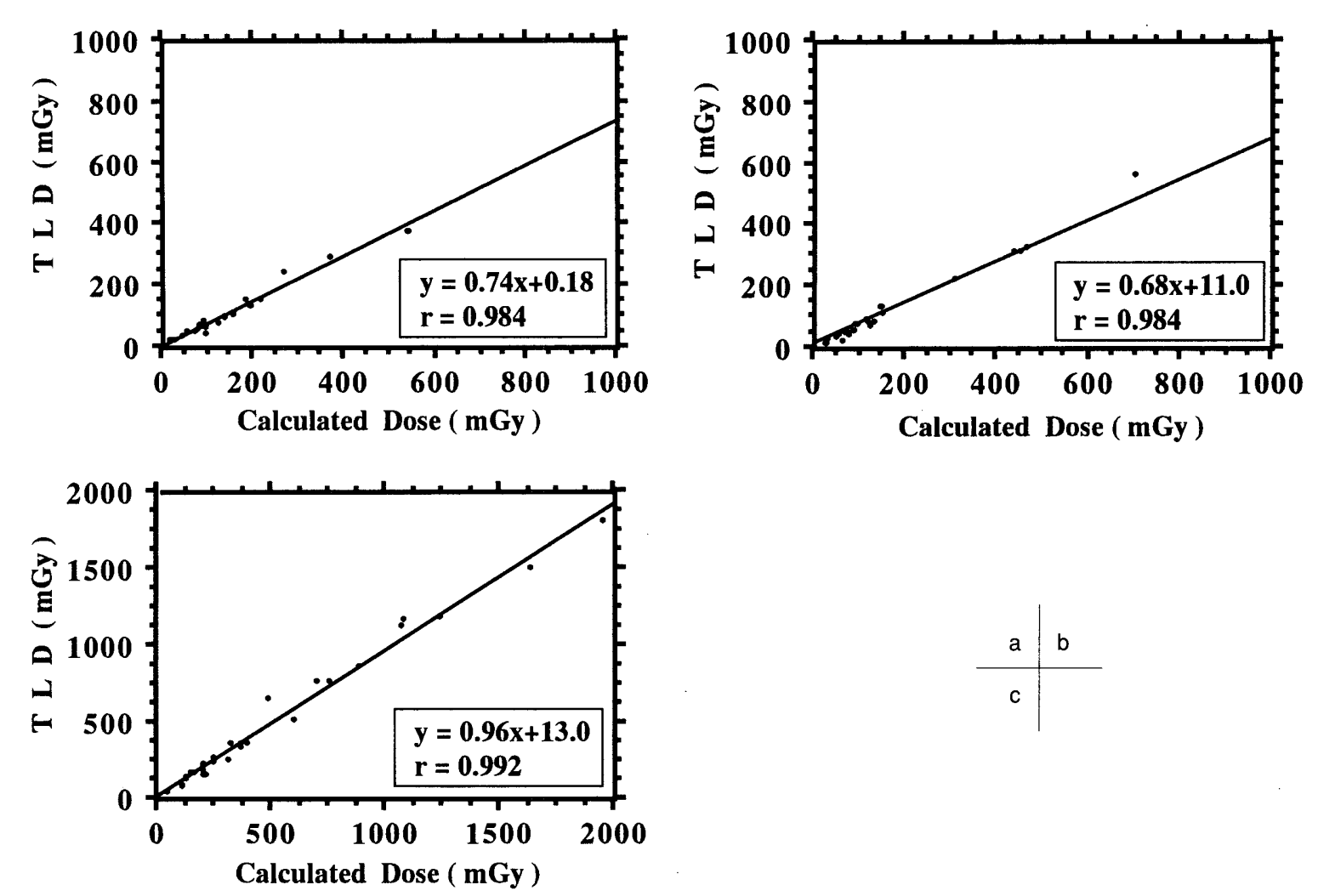

Fig. 7 Entrance skin dose measured by TLD and incident dose at the interventional reference point calculated from dose area product depending on direction of projection in the clinical setting.
(a) Postero-anterior direction.
(b) Right anterior oblique direction of 30 degrees.
(c) Left anterior oblique direction of 60 degrees.

評価する. I.I.の距離変化に伴い面積線量が変化(装置 から出力されるX線量が変化) LFig. 4(a)の入射面積比 も変化しているため, 相対線量值の変化は小さかった と考えられる，なお，装置の照射野はFIDの変化に連 動し自動調整されている.

基礎的実験結果からインターベンショナル基準点で の入射線量を代表値とした場合，幾何学的配置の変化 においてI.I.の移動に比較し被写体の移動は大きな影 響があると考えられる。また，Fig. 3(b) とFig. 4(b)よ り，被写体が管球から遠ざかりI.I.が近づく配置にお いて2.2倍の過大評価が起こり，被写体が管球へ近づ きI.I.が遠ざかる配置において 0.77 倍と過小評価が起 こり得るので注意が必要であると考える。

\section{3-2 臨床応用}

臨床に扮ける皮膚入射面積を把握することは，間接 測定法での精度を推定するうえで重要となる．各方向 における40例の頻度分布を計測した結果 (Fig. 5)，イ ンターベンショナル基準点での入射面積に比較し，正 面とRAO30度方向では全体的に皮虚入射面積は広い 部分に分布し，LAO60度方向では基準点の入射面積
を中心とするような分布となった。このことから，イ ンターベンショナル基準点に扔ける入射線量で各方向 の入射皮膚線量を推定する場合，正面とRAO30度方 向では過大な線量推定となりLAO60度方向では比較 的精度良く推定可能であることが考えられる。また， インターベンショナル基準点での焦点-基準点間距離 $55 \mathrm{~cm}$ に対し，正面方向〔Fig. 5(a)]での焦点-皮膚間距 離は約61 68cm, RAO30度方向[Fig. 5(b)]では約58 $\sim 66 \mathrm{~cm}$, LAO60度方向 [Fig. 5 (c) ]では約 $49 \sim 60 \mathrm{~cm}$ の 範囲に分布していた。

面積線量計から (1)式にて推定したインターベンシ ヨナル基準点での入射皮膚線量とTLDによる実測值を 比較した結果[Fig. 6(a)]，両者は強い相関が得られた が，基準点での入射皮膚線量は実測值より1.17倍程度 の過大評価をする傾向にあった。また，(1)式にて実 測した皮膚入射面積を用い入射皮膚線量と比較した結 果[Fig. 6(b)]，両者は強い相関が得られ精度高く推定 が行われた。このことから, Fig. 6(a)の過大評価の原 因は基準点での入射面積に依存していると考えられ る.さらにFig. 6(a)を各角度ごとに基準点での入射皮 膚線量と実測值を評価した場合 (Fig. 7)，正面方向で 
は1.36倍過大評価し[Fig. 7(a)], RAO30度方向では 1.47倍過大評価し[Fig. 7(b)], LAO60度方向ではほほ 正確な線量を表していた[Fig. 7(c)].

臨床において，LAO60度方向ではX線管球の振り角 度が大きく，X線が被写体を斜入し焦点-皮虚間距離が 短くなり，インターベンショナル基準点と皮膚面がほ ぼ同じ位置関係になったため，基準点での入射皮虐線 量が実測値とほぼ同様になったと考えられる．正面， RAO30度方向ではI.I.に被写体を近づけ検査を行うこ とにより，インターベンショナル基準点よりI.I.側に 皮膚面が位置し，基準点での入射皮膚線量は実測值よ り過大評価する傾向になった．また，各角度での傾向 は皮膚入射面積測定の結果 (Fig. 5)を反映していると 考えられる。

\section{3-3 インターベンショナル基準点の有効利用}

患者被曝線量を測定する場合，一般的には直接測定 法を用いるが，多くの施設では行われていない現状に あると考える。その理由として，測定が煩雑であるこ と, 測定器具が普及していないこと, そして成人心血 管領域のIVRでは大半が短時間で手技を終了するため と考える. Fig. 8に当施設におけるIVRでの一症例当 たりの患者皮膚線量のTLDによる測定結果を示す11). 心血管領域のIVRは頭部，腹部領域のIVRより平均的 に入射皮膚線量は低く1Gy以下であるが，3Gyを超え る症例も存在する。このように少ない症例ではある が, 大線量が照射されるケースが存在するため放射線 皮虚障害の発生する可能性が示唆される。このため, リアルタイムで簡便な被曝線量測定法が重要になると 考える。

皮膚線量測定を面積線量計により臨床で利用する場 合(1)式を用いているが，リアルタイムに皮膚入射面 積の值を求めることが難しい現状にある. インターベ ンショナル基準点の設定により，推定点が統一される ため皮虐入射面積 (SEA) が一定となり, 補正係数値 （I，T，F）は事前に得られていることから，面積線量 値を代入することにより，容易でリアルタイムに基準 点への入射皮膚線量を推定することが可能となった。 このことは，面積線量計を簡便に臨床利用するための 有効な方法であると考える.

IEC嫢格ではインターベンショナル基準点での空気 カーマの表示を装置に要求している. 空気カーマ表示 では，後方散乱係数と組織線量変換係数を乗じること により皮膚吸収線量へ変換でき, 臨床で使用する線 質・照射面積では空気カーマの1.3〜1.4倍することに より皮虐吸収線量が求められる12,13). 装置の表示値が どのような線量を示しているかを理解し利用すること が重要であると考える。

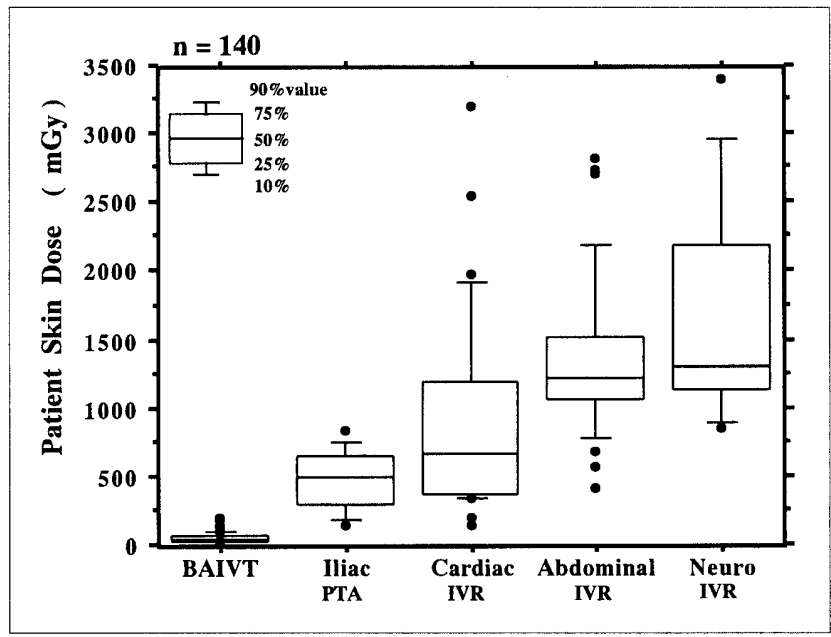

Fig. 8 Distributions of patient skin dose measured by TLD for each interventional radiology (IVR) study.

また，インターベンショナル基準点での線量表示は 積算線量 (積算面積線量)である。このため, 最大皮膚 線量の推定は難しいと考えられる。しかし，Fig. 8に 示すように心血管領域のIVRでは，平均線量より大幅 に高くなる入射皮膚線量が問題となり，このような症 例では同一角度にて透視や撮影を行うことから，総積 算線量を最大線量として推定することにより9)，安全 側で管理する方法もあると考える。将来的には角度ご との積算線量を装置により解析し, 最大線量が表示さ れるシステムの構築が望まれる。

以上より，成人心血管領域の検査に適用されるイン ターベンショナル基準点は，その点での入射皮膚線量 と患者入射皮膚線量との間にある程度の誤差を含む が，間接測定法における統一的な基準点として線量推 定に有用であると考える。また，インターベンショナ ル基準点は将来的にJIS化される可能性が高く，その 規格は臨床における被曝線量管理を進歩させる一つの 方法であり，基準点での線量表示值の特性を理解し有 効に活用すべきであると考える，今後は，成人心血管 領域以外の部位への基準点の設定，推定精度の向上， 積算総線量測定から最大線量測定とその部位の表示へ と規格化の進むことが望まれる。

\section{4. 結 語}

IECにて規格化され成人心血管領域に適応されるイ ンターベンショナル基準点での入射線量值の精度につ いて基礎的検討を行い, 臨床応用の可能性について検 討した。

基礎的検討において，インターベンショナル基準点 での入射線量にて入射表面線量を代表した場合， 2.2 倍の過大評価から 0.77 倍の過小評価が起こる可能性が あった。臨床応用では，面積線量計によるインターベ 
ンショナル基準点での入射皮膚線量はTLDによる実測 值と比較し，1.17倍程度の過大評価をする傾向にあっ た。また，正面方向，RAO30度方向では過大評価し， LAO60度方向ではほほ正確な線量を表していた。

インターベンショナル基準点は，間接測定法におい てリアルタイムで簡便に線量推定を行うために有用な 規格であると考える。

\section{謝 辞}

稿を終えるにあたり，臨床でのデー夕収集に快くご
協力いただきました当院第二内科循環器グループに感 謝の意を表します。また，貴重なご助言をいただきま した，日本放射線技術学会「IVRに扔ける患者被曝線 量の測定と防護に関する研究班」班長の水谷 宏氏, 班員の梅津芳幸氏，江口陽一氏，菊地 透氏，山口和 也氏に御礼申し上げます。

なお，本要旨の一部は第30回日本放射線技術学会秋 季大会において発表した.

\section{参考文献}

1) Cascade PN, Peterson LE, Wajszczuk WJ, et al.: Radiation exposure to patients undergoing percutaneous transluminal coronary angioplasty. Am J Cardio, 59, 996-997, (1987).

2) Shope TB: Radiation-induced Skin Injuries from Fluoroscopy. Center for Devices and Radiological Health, FDA, (1997).

3) Vano E, Goicolea J, Galvan C, et al.: Skin radiation injuries in patients following repeated coronary angioplasty procedures. Br J Radiol, 74 (887), 1023-1031,(2001).

4）富樫厚彦：IVRに伴う放射線皮膚障害報告症例から放射線 防護を考える．日放技学誌，57(12)，1444-1450，(2001).

5) 森 剛彦, 田村正夫, 高橋雪夫, 他: X線診断領域の表面 線量測定の簡易換算法．日放技師会誌，33(1)，13-28， (1986).

6) 江口陽一, 木村 均, 土佐鉄雄, 他 : 被検者被曝線量の実 用的な測定方法. 全循研誌，12，14-17，(2000).

7) 新開英秀, 江副正輔, 重谷 昇, 他：患者被曝線量計とし て開発した小型電極電離箱の特性評価. 日放技学誌，52
(5), 639-644, (1996).

8）坂本 肇, 中村 修, 弓削 誠, 他：面積線量計による患 者被曝管理の検討。日放技学誌，56(10)，1256-1265， (2000).

9）水谷 宏, 梅津芳幸, 江口陽一, 他：IVRにおける患者被 曝線量の測定と防護に関する研究班報告：日放技学誌，59 (3), 369-381, (2003).

10) Medical electrical equipment - Particular requirements for the safety of X-ray equipment for interventional procedures. IEC 60601-2-43, (2000).

11）坂本 肇，深澤瑞也，武田正之，他：BAIVTにおける術者 と患者の被曝線量. 日本透析医学会雑誌，36(6)，11991205, (2003).

12) The British Journal of Radiology Suppl.10,(1961).

13）西谷源展：ディジタルX線画像の画質と被曝 1)X線計測に おける問題点. 日放技学誌，52(11)，1579-1582，(1996).

Fig. 1 インターベンショナル基準点の幾何学的位置

Fig. 2 基礎的実験の幾何学的配置

(a) 焦点-被写体間距離 (FSD) を50 79cm と変化, 焦点-I.I. 間距離(FID) $100 \mathrm{~cm}$ 一定

(b) 焦点-I.I. 間距離 (FID) を $87 \sim 110 \mathrm{~cm}$ と変化, 焦点-被写体間距離 (FSD) $55 \mathrm{~cm}$ 一定

Fig. 3 焦点-被写体間距離の変化におけるファントム表面とインターベンショナル基準点での入射面積および入射線量の相対値 (a)インターベンショナル基準点での入射面積に対する表面入射面積の相対值(表面入射面積/インターベンショナル基準点 での入射面積)

(b)インターベンショナル基準点での入射線量に対する各入射表面線量の相対値(入射表面線量/インターベンショナル基準 点での入射線量) と面積線量

Fig. 4 焦点-I.I.間距離の変化におけるファントム表面での入射面積抆よび入射線量の相対值

(a)焦点-I.I.間距離が $100 \mathrm{~cm}$ での入射面積に対する各表面入射面積の相対值(表面入射面積/焦点-I.I.間距離 $100 \mathrm{~cm}$ での入射面積) (b) 焦点-I.I.間距離が $100 \mathrm{~cm}$ での入射表面線量に対する各入射表面線量の相対值 (入射表面線量/焦点-I.I. 間距離 $100 \mathrm{~cm}$ での入 射表面線量) と面積線量

Fig. 5 臨床での皮膚入射面積と患者数の関係
(a) 正面方向
(b) RAO30度方向
(c)LAO60度方向

Fig. 6 臨床におけるTLDと面積線量計から推定した入射皮膚線量の関係

(a) 面積線量から推定したインターベンショナル基準点での入射線量

(b) 面積線量から推定した入射皮虞線量

Fig. 7 臨床におけるTLDと面積線量計から推定したインターベンショナル基準点での入射線量の関係を撮影方向別に比較

(a) 正面方向

(b) RAO30度方向

(c) LAO60度方向

Fig. 8 IVRでの一症例当たりの患者皮膚線量 